\title{
Progressive Science in Public Welfare and Modern Industry*
}

$\mathrm{T}^{\mathrm{H}}$ HE Department of Scientific and Industrial Research now occupies such an essential place in the scientific and industrial structure of the country that it is already hard to realize that it is little more than twenty years since it first came into existence. The recently issued twentyfirst annual report of the Department indicates the remarkable success of the Department in stimulating a new outlook in British industry, and can point to welcome evidence of increased support for research from a considerable number of industries in the last year. The most admirable feature of the report, however, is the lucid and comprehensive picture it gives of the contribution of science to the service of the needs, not merely of industry but also of every aspect of our daily lives, whether as a nation or as private citizens. From the requirements of the defence forces and other Departments of State, to the primary needs of the humblest citizen in respect of water supply, food, transport, clothing and recreation there is scarcely a question to which some contribution is not made by the Department. Moreover, the growing complexity of many of the issues involved in some questions, as food supply, national defence, roads and road safety, render the more valuable such a comprehensive picture as is regularly afforded by the annual report of the Department.

The present report, which covers the period October 1, 1935-September 20, 1936, contains the brief report of the Committee of the Privy Council, signed by the Right Hon. J. Ramsay MacDonald, Lord President of the Council, the report of the Advisory Council, over Lord Rutherford's signature and summaries of the work of the National Physical Laboratory, the Chemical Research Laboratory, and of the various research associations, and research boards or committees.

The gross expenditure of the Department in $1935-36$ was $£ 787,186$, or $£ 571,831$ net as against $\$ 549,751$ net in 1934-35. The largest single item of expenditure was $£ 109,038$ on the National Physical Laboratory, the gross expenditure of $£ 234,383$ covering, however, the cost of work carried out at the Laboratory for the Food Investigation Board, the Radio Research Board, and other Research Boards of the Department. Against this gross total, receipts amounted to $£ 125,345$, of which $£ 65,950$ represents fees from industry for paid work. Other receipts against the gross expenditure of the Department include $£ 63,878$ in

* Department of Scientific and Industrial Research. Report for the Year 1935-36. (Cmd. 5350.) Pp. iv +195. (London: H.M. 8tationery Office, 1937.) 3s. net. payments by other Government departments for services rendered, $£ 32,623$ from the Road Fund and $£ 9,800$ from the Empire overseas for food investigation. Expenditure on the Chemical Research Laboratory was $£ 21,697$, on food investigation $£ 43,296$ net, on building and road research $£ 78,218$ gross, or $£ 33,655$ net, on forest products research $£ 38,983$ net, on fuel research $£ 87,501$ net and on water pollution research $£ 13,968$ gross or $£ 4,354$ net. Expenditure on the Geological Survey and Museum amounted to $£ 66,641$ net, while grants to Research Associations amounted to $£ 108,951$ as against $\mathfrak{1 8 5 , 3 8 4}$ in $1934-35$ and $\mathfrak{f 5 8 , 9 9 2}$ in $1933-34$.

Special stress is laid in the report on the progress of the Research Associations, and encouraging evidence of development in this field is the increased contribution of the industries concerned to the support of these associations. In the three years since the Million Fund came to an end in $1932-33$, this figure has grown from $£ 167,370$ to

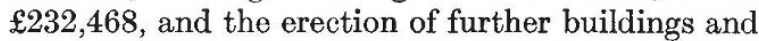
the extension of equipment which have marked the past year indicate the growing faith of industry in the value of research. New laboratories of the Electrical Research Association costing more than $£ 29,000$ were opened at Perivale. The Research and Standardisation Committee of the Institution of Automobile Engineers-the co-operative research organization of the motor industry-has acquired and equipped new laboratories costing $£ 20,000$ on the Great West Road. The laboratory accommodation of the Paint Research Association has been considerably enlarged. Extensions involving expenditure of $£ 41,000$ have been opened at the Shirley Institute (cotton research), where the buildings now cover an area of more than three acres and the total cost of laboratories and equipments has passed $£ 200,000$. The income of the Cotton Research Association, the largest of the research associations, has now reached $£ 84,000$ and its staff last year numbered 270 .

The position of the research association movement as a whole is not, however, regarded as entirely satisfactory. The Department is prepared to provide a further $£ 66,000$ for the support of the Research Associations, and would have found that sum in each of the last two years had industry been ready to provide an equivalent contribution. In fact, had full advantage been taken of the offer of the Department, the income of the associations would have been increased by a further $£ 150,000$ a year. In some cases only two years 
now remain in which the industry can earn the balance of additional grant still available. A new development in the year has been the conversion of the Printing Research Association from merely an efficient information bureau, serving the printing industry, the paper-making industry and the printing ink manufacturers, into an organization which adds to knowledge by research. Additional staff has been engaged, and laboratory premises, opened by H.R.H. the Duke of Gloucester on March 9 of this year, have been equipped.

To turn from the prosaic survey of ways and means to results achieved, it is almost startling that industry anywhere should be so backward in supporting the work of the Research Associations, which makes such important contributions not only to ind ustrial welfare but also to social amenities and well-being. The examination by the Iron and Steel Industrial Research Council of data of works operation, for example, has led to a rapid improvement in productive efficiency and reduction of fuel consumption even in works which were regarded as highly efficient. Moreover, the greatly increased control by scientific instruments in steel making has led to robust apparatus of high precision for such work being made by British firms at prices competitive with foreign apparatus. A comprehensive investigation on steel sheet has been initiated in co-operation with the research organization of the automobile industry. The British Non-Ferrous Metals Research Association has continued its work on the corrosion of copper with particular reference to water service pipes as well as that on the corrosion of lead.

Mainly as a result of the work of the British Refractories Research Association, the life of the silica brick linings of gas retorts is now 25 per cent longer than ten years ago, and the economies resulting to the gas industry are very large. The Electrical Research Association has developed a new type of fuse for radio receivers or electrical clocks which combines a close degree of protection with a greatly increased time lag. Other of its work has been concerned with interference with broadcasting from electric appliances in common use, and with earthing conditions for overhead lines which will protect cattle grazing under them from shock if faults develop on the lines. An interesting investigation carried out by the Paint Research Association of particular interest to the householder is that of painting in winter and in wet weather, and of methods of overcoming the difficulties or ill-effects due to such conditions by simple modification in the composition of the paint.

The close bearing of the work of the Research Associations on everyday life is indeed remarkably illustrated in the present report. A community which is making ever greater use of the motorcar, whether for private or for public transport, can scarcely fail to appreciate the importance of the co-operative research which has made cylinder wear in automobiles no longer the serious problem it presented a few years ago. Gas masks are unfortunately now presenting a civilian interest as well as an industrial interest or one confined to the defence forces of the Crown, but the importance of the work of the Rubber Research Association in developing durable rubber components for such masks and in devising tests to ensure that supplies of reliable articles are available is obvious. Equally of interest, in view of the increasing use which is made of rubber as a constructional material in buildings, is work on the development of rubbers resistant to fire and heat.

Work on rubber is related to comfort as well as to safety, however, and the Association has also been investigating methods of measuring the hardness of rubber which will enable its cushioning properties in reducing noise and vibration to be evaluated more accurately. A particularly interesting piece of work of the Association has been concerned with the resistance to wear of rubber soles and heels, which has enabled the durability of rubber footwear to be increased. The Leather Manufacturers' Research Association has also been concerned with footwear, and has undertaken an important investigation on the quality of sole bands for shoe manufacturers with special reference to the suitability of the leather for light stuck-on soles. The boot, shoe and allied trades have their own Research Association, however, and this has been responsible for an outstanding development in what may be called the initiation of research on walking. To assist manufacturers to design better fitting shoes, the Association has devised a means of making very careful records of the way in which various people walk. A cinematograph record is taken by means of a moving platform or treadmill of the movements of the foot, and is afterwards carefully analysed. The gaits of individuals and the effect of different kinds of shoe upon them are being investigated, and the results already obtained suggest that some shoes are much more likely than others to interfere with the usual gait. The significance of such a contribution from the point of health is difficult to assess, but may well be of great importance.

Equally significant is the work of the Flour Millers' Research Association on the keeping qualities of bread. What the housewife calls 'staling' is usually due to poor keeping qualities in the bread. Bread made in the best possible way from the best possible flour will retain its edibility for ten or twelve days, whereas bread improperly made from poor flour may become 
unappetizing and almost uneatable in two or three days. The work already carried out suggests that if more attention were paid to commercially controllable factors which promote the good keeping quality of bread, the question of stale bread would be much less serious.

This aspect of bread staling is not, however, true staling, which is caused by a change in the nature of the starch in the bread from its natural form at high temperatures to the natural form stable at low temperatures. If true staling could be prevented, the bread would probably always keep well, but, in practice, methods which would prevent the transformation are liable to accelerate the growth of moulds. Other work of the Association has been concerned with the storage of flour and the fats of flour, while the Research Association for the Cocoa, Chocolate, Sugar, Confectionery and Jam Trades has been investigating the problem of the attack of starch products by insect pests and has already been of much assistance in the suppression of such pests. Other work of this Association on the jellifying properties of various pectins has led to the improvement of conditions for the manufacture of marmalade from oranges.

Many other investigations on food problems, particularly those relating to the storage and transport of food, for which the Food Investigation Board is responsible, are referred to in the report. At the Low Temperature Research Station at Cambridge the lethal effect of X-rays on bacteria has been studied in connexion with the storage of meat. Methods of storing eggs in different concentrations of carbon dioxide are being tried out on a large scale. Another investigation is concerned with the relation between the quality of pork and bacon and the growth and diet of the pig; and the advantage in dry salt cures of resting the pig adequately before slaughter has been established. The storage and salt curing of herrings, the gas storage of apples, pears and other fruits and vegetables, and canning questions, are other examples of the way in which the work of the Department is tending to improve food supplies and assist in questions of adequate and balanced diet.

Nor are boots and shoes the only point at which the work of the Department touches the clothing of the citizen. The work of all the textile research associations bears closely upon many such matters. The new silk section of the Cotton Research Association, for example, is contributing materially to the solution of problems involved in the use of mixed fabrics of cotton, silk and rayon. The Linen Research Association has been concerned with the laundering of linen fabrics and their resistance to weathering and to fading when dyed, while besides its important work on the resistance of wool to shrinking the Woollen Industries
Research Association has been responsible for fundamental research now widely exploited in the 'permanent waving' of ladies' hair. The housewife should be equally appreciative of the work of the Launderers' Research Association on the washing of woollens, on the development of fastness standards for coloured goods and on the properties of detergent solutions.

Reference has already been made to contributions made by the Department in matters of safety. No aspect of the work of the Colliery Users' Research Association is more important than this, whether in respect of dust suppression and the prevention of silicosis, underground illumination or the control of atmospheric conditions in mines. An important investigation has been commenced at the National Physical Laboratory on the production of static electrification in operating theatres of hospitals, which should enable the risks of ignition of anæsthetics by sparking to be considerably reduced. A preliminary investigation on the similar risk in dry-cleaning works has been undertaken at the request of the Home Office.

Among other work bearing directly on health and safety may be mentioned that on industrial respirators and the detection of toxic gases in industry, research on the composition of dental amalgams, their manufacture and use, the radium treatment of disease, atmospheric pollution, in which field a survey on a large scale of the pollution in and round the City of Leicester is to be undertaken, and the investigations in chemotherapy at the Chemical Research Laboratory. Moreover, at the present time, the significance of much of the work of the Road Research Board, whether in road construction or road usage, such as questions of skidding and its prevention, needs no emphasis in this connexion. Work on water pollution, too, has yielded results as important from the health point of view as from that of the considerable savings which have been achieved, for example, for the dairy and milk industry, through the improved disposal of their effluents.

The Building Research Station is scarcely of less importance to the householder than to industry, and besides the improvement of bricks and cements, the durability of building stone and the structure and strength of materials, has covered questions of fire prevention, for which purpose a Fire Testing Station has been opened, and the efficacy of buildings from the point of view of users as regards heating, ventilation, lighting, or the transmission of noise.

The Illumination Research Board has been concerned not only with lighting, or such problems as the effect of glare on vision, but also with problems in connexion with automobile headlights. Space does not permit even mention of other 
investigations carried out at the National Physical Laboratory or at the Chemical Research Laboratory, by the Forest Products Research Station, the Fuel Research Station, the Lubrication Research Board, in metallurgical matters, furnace design, aircraft design and other fields which have yielded equally significant results for industry or the general advantage of the community. A final reference can only be made to the discovery in radio research, which is one of the most interesting of the year, of the existence of three new electrified regions in the atmosphere between 4 and 40 miles above the earth. These regions are thus well below the well-known Heaviside and Appleton regions, which play such an important part in broadcasting to great distances and in making Empire com. munication on short waves possible.

Enough has been said, however, to demonstrate the value of the work of the Department alike in the latest fields of scientific activity and investigation and in the very oldest on which industrial prosperity and civic welfare alike depend. No doeument could in fact be better calculated to show the contribution which scientific research can make to human welfare and progress if it is applied to constructive and social ends, and not prostituted for destructive purposes as in preparations for war.

\section{Boron and the Control of Plant Disease}

\section{By Dr. Winifred E. Brenchley}

$\mathrm{T}^{\mathrm{n}}$ HE value of boron in improving plant growth was indicated in the early part of this century by various workers, notably Agulhon ${ }^{1}$, but it was not until 1923 that its essential nature was definitely proved by Warington ${ }^{2}$ in her work on the broad bean. Since then, research workers and practical men have taken up the matter all over the world, and various obscure physiological diseases of crops have been traced to a deficiency of boron in the soil. Crown rot of sugar beet, raan in swedes, topsiekte of tobacco and certain leafroll diseases of potato all respond favourably to the application of small dressings of borax, usually ranging from $10 \mathrm{lb}$. to $20 \mathrm{lb}$. per acre for these relatively short-lived plants. Heavy dressings of boron compounds are unfavourable as they produce toxic symptoms which may cause grave damage.

During the last few years, active experimental work has been carried out in widely separated centres on the control of cork disease, corky core, or internal cork of apples, all apparently representing the same trouble. The surface of the fruit becomes uneven, and brown areas of diseased tissue are distributed throughout the apple, particularly around the core, greatly reducing the market value of the crop.

Acting on a suspicion that the disease was due to the deficiency of some essential element, McLartys tested thirty chemicals by injecting them into the trunks of affected trees. Of these, boric acid and manganese borate proved effective in controlling corky core, as with injections above a minimum of $1.83 \mathrm{gm}$. per $100 \mathrm{sq}$. $\mathrm{cm}$. of the cross-sectional area of the trunks no disease occurred, and the total crop was greatly increased.
Heavier doses up to $5.92 \mathrm{gm}$. did not cause any damage to the foliage, though there was slight injury to the bark and cambium at the point of injection. In these experiments the test material was nearly always packed into the trunks in the dry form, because of the greater convenience in handling and also because larger amounts could be used without injury to the foliage.

At the same time, Askew and his collaborators in New Zealand ${ }^{4}$ and Jamalainen ${ }^{5}$ in Finland were also investigating the problem. In New Zealand boron again proved to be the effective controlling agent out of a large number of elements tested, and the method of getting it into the tree seems to be largely a matter of convenience. Borax spread broadcast at the rate of $\frac{1}{2}-1 \mathrm{lb}$. per tree or $50-100 \mathrm{lb}$. per acre rapidly penetrates the soil to the absorbing zone of the roots in a favourably moist season, and is taken up and passed into the leaves and fruit, giving good control of internal cork. The penetration might not be so good or rapid in a dry season, but there is a considerable safety margin, as the normal annual requirement per acre for leaf and fruit growth has been found by analysis to be only about $14 \mathrm{oz}$. of borax. Injections of solution containing 0.25 per cent of hydrated borax were equally effective in increasing the boron content of leaves and fruit, and internal cork was prevented by so little as $2.5 \mathrm{gm}$. borax per tree. Where the injections were made into a branch, a certain amount of migration of boron took place into untreated branches, even when the point of injection was some way above the crotch. Similar control was obtained by applying borax sprays at the rate of one gallon per tree, and the suggestion is made that two applications 